\title{
Master Production Scheduling ANd The Relevance OF InCluded Social Criteria
}

\author{
Marco Trost $^{1}$; Thorsten Claus $^{2}$; Frank Herrmann ${ }^{3}$ \\ ${ }^{1,2}$ Technische Universität Dresden (TU Dresden) \\ Faculty of Business and Economics, \\ International Institute Zittau, \\ Markt 23, 02763 Zittau, Germany \\ ${ }^{3}$ Ostbayerische Technische Hochschule Regensburg (OTH Regensburg) \\ Faculty of Computer Science and Mathematics \\ Innovation and Competence Center for Production Logistics and Factory Planning (IPF) \\ Prüfeninger Str. 58, 93049 Regensburg, Germany \\ e-mail: ${ }^{1}$ marco.trost@mailbox.tu-dresden.de; ${ }^{2}$ thorsten.claus@tu-dresden.de; \\ rank.herrmann@oth-regensburg.de
}

\begin{abstract}
The requirements to consider worker utilizations and processing times, which depends on this worker utilization, are examined at the following paper for the Master Production Scheduling. For this reason, it is shown, that there is a gap in research regarding the social dimension in the range of Production Planning and Control. Thus, there are presented an own developed linear optimization model for the Master Production Scheduling with consideration of social criteria and an appropriate case study at this paper. The results demonstrate substantial deviations due to the ignorance from worker utilizations and worker utilization specific processing times. Therefore, the integration of these criteria is to be recommended. But it is also shown, that there is a need for further research activities for the development of specific human fatigue courses, like it also exists for human learning courses.
\end{abstract}

\section{Keywords}

Sustainability; Production planning and control; Master production scheduling; Linear optimization; Human fatigue.

\section{Introduction}

The justification from production systems in a more sustainable direction is one of the central research focuses actual. But there is to mention, that economical, ecological and social criteria have to be considered to achieve sustainability [1] and in this context, there are substantial potentials in the field of Production Planning and Control (PPC) [2] [3] [4]. So, the resource consumption is influenced due to the production plan, which has to be determined. Thus, ecological and social issues like energy consumption or worker's stress are affected next to the classical economical monetary assessment [5]. In this process, the ecological dimension is already explored broadly (see: [6] [7] [8]). However, there is a gap in research for the social dimension at the field of PPC. Here the papers from [9], [10] as well as [11] have to be mentioned, who considered human learning and forgetting effects for a Lot-Sizing problem and reduce worker's stress for a specific Scheduling problem. Especially in consideration of the already proven Hierarchical Production Planning system from [12], it should be noted, that there are no appropriate approaches for the consideration of the social dimension at the level of Master Production Scheduling, which is the top level at the Hierarchical Production 
Planning system from [12]. This lack of social improvements is also affirmed by the paper from [13], who reports, that there are only smart improvements for worker conditions in spite of different research activities. Especially the physical stress and the work intensity are rated to be too high out of 11 defined criteria [13]. For this reason, an extended version of the linear optimization model for the Master Production Scheduling with consideration of social criteria from [5] is presented at this paper and as an extension to the studies in [5] there is also presented an investigation regarding the necessity to integrate social criteria based on a more comprehensive case study.

\section{$1 \quad$ Linear Optimization Model for Master Production Scheduling}

In classical models as a restriction for the production plan at the level of the Master Production Scheduling there are defined stipulated limits for existing capacities. But a compensation for capacity bottlenecks are doable due to a production in advance or by using overtime hours, so that the minimization of costs for inventory and overtime hours is the goal in such models [14]. Furthermore, constant processing times for each quantity unit per product are assumed. Now the linear optimization model, which is based on this standard, is described. The consideration of costs for shift bonuses, the possibility of different worker utilizations for each production segment and the specification of the worker utilization as an interval are the extensions to the model, which is introduced in [5].

The integration of a variable personnel supply of capacity, see Equation (5), is the first essential improvement at this model. Thereby it is also considered, that there are requirements for lead times to adjust capacities. For the consideration of social criteria this all is imperative, because this connects elements of the human resources management with the PPC and in that order not only the human resources management has to provide the necessary capacities but also the PPC has to consider the workers requirements [5]. In addition, the limitation of a maximum supply of technical capacity, see Equation (6), remains unchanged. The determination of a fixed relation (worker utilization), see Equations (11) and (12), between supply of capacity, see Equation (5), and capacity requirements, see Equation (4), is the second essential improvement at this model. This ensures that workers cannot be overloaded. Next to the classical production plan, see Equations (2-4), the number of workers required, see Equations (5-7), is also determined. Thereby different classes of workers are also considered for every production segment. Further, intern conditions from the company and extern conditions from the labor market are integrated by defining initial, minimal and maximal numbers of employees, see Equations (8-10),. The objective function (see equ. 1) is calculated by minimization the sum of storage costs, manpower costs, costs for shift bonuses as well as costs for building and removing capacities. For this purpose, the appropriate shift model (one, two, or three shifts) due to the number of employees is also determined, see Equations (13-15).

Compared to the basic model from [14] the consideration of worker utilization specific processing times is the third essential improvement at this model. But these processing times are determined as parameters, because a non-linearity is caused by a direct calculation within the optimization model. Therefore, the processing times are calculated extern by multiplication from standard processing times with weighting factors, which are derived from fatigue courses due to the worker utilization. Then, to receive the optimal solution the optimization model is solved for all worker utilization constellations and the associated processing times. Now the mathematically model description is presented. 


\section{Parameters:}

$a_{j, t}^{\max } \quad$ Maximum supply of technical capacity

$d_{k, t}$

Product requirements per product $\mathrm{k}$ and time period $t$

$f_{j, k, z}$

Capacity requirement per production segment $j$, product $k$ and forerun period $z$

$h_{k}$

Cost rate for storage per product $k$

$I_{k}^{\text {init }}$

Initial inventory per product $k$

$J$

Number of production segments $(j=1,2, \ldots, J)$

$K$

Number of products $(k=1,2, \ldots, K)$

$K A P A_{m a, t} \quad$ Supply of capacity per worker of a worker class $m a$ and time period $t$

$m^{\text {Kost }}$

$M A$

Cost rate for building supply of capacity

Number of worker classes $(m a=1,2, \ldots, M A)$

Mit $_{m a, j, s}^{\text {init }}$

Mit $_{m a, j, t}^{\text {Kost }}$

Initial number of worker per worker class $m a$, production segment $j$ and shift $s$

Mit $_{m a, j, t}^{\max }$

Mit $_{m a, j, t}^{\min }$

$n^{\text {Kost }}$

Cost rate per worker of class $m a$, production segment $j$ and time period $t$

Maximum number of worker per worker class $m a$, production segment $j$ and time period $t$

$R_{j}^{\max }$

Minimum number of worker per worker class $m a$, production segment $j$ and time period $t$

$R_{j}^{\min }$

Cost rate for removing supply of capacity

$S$

Maximum worker utilization per production segment $j$

Minimum worker utilization per production segment $j$

$S_{s}^{\text {Kost }}$

Number of shifts $(s=1,2, \ldots, S)$

$S_{j, s}^{\text {Oben }}$

Cost factor for calculating shift bonuses per shift $s$

$S_{j, s}^{U n t}$

Maximum limit for number of worker per production segment $j$ and shift $s$

$T$

Minimum limit for number of worker per production segment $j$ and shift $s$

Planning horizon in time periods $(t=1,2, \ldots, T)$

$W \quad$ Number of forerun periods for removing supply of capacity $(w=W)$

$Y \quad$ Number of forerun periods for building supply of capacity $(y=Y)$

$Z$

Number of forerun periods for production $(z=1,2, \ldots, Z)$

\section{Decision variables:}

$a_{j, t} \quad$ Supply of capacity per production segment $j$ and time period $t$

$b_{j, t}$

Capacity requirement per production segment $j$ and time period $t$

$I_{k, t}$ Inventory per product $k$ and time period $t$

$m_{m a, j, t}$

Number of worker recruitments per worker class $m a$, production segment $j$ and time period $t$

$M_{i t} t_{m a, j, s, t} \quad$ Number of worker per worker class $m a$, production segment $j$ and time period $t$

$n_{m a, j, t}$ Number of worker redundancies per worker class $m a$, production segment $j$ and time period $t$

$p_{j, s, t} \quad$ Boolean variable for calculating the number of shifts per production segment $j$, shift $s$ and time period $t$ 


\section{Objective function to minimize:}

$$
\begin{aligned}
& \sum_{t=1}^{T} \sum_{k=1}^{K} h_{k} \bullet I_{k, t}+\sum_{t=1}^{T} \sum_{s=1}^{S} \sum_{m a=1}^{M A} M_{i t} \operatorname{tost}_{m, j, t} \bullet M_{i t} t_{m a, j, s, t} \\
& +\sum_{t=1}^{T} \sum_{s=1}^{S} \sum_{m a=1}^{M A} M_{i t}^{\text {Kost }} \bullet M_{m a, j} \operatorname{Mit}_{m a, j, s, t} \bullet \boldsymbol{s}_{s}^{\text {Kost }} \bullet p_{j, s, t} \\
& +\sum_{t=1}^{T} \sum_{j=1}^{J} \sum_{m a=1}^{M A} m_{m a, j, t}^{\text {Kost }} \bullet \boldsymbol{m}_{m a, j, t}+\sum_{t=1}^{T} \sum_{j=1}^{J} \sum_{m a=1}^{M A} n_{m a, j, t}^{\text {Kost }} \bullet n_{m a, j, t}
\end{aligned}
$$

\section{Constraints:}

$$
\begin{aligned}
& \boldsymbol{X}_{k, t}+\boldsymbol{I}_{k, t-1}-\boldsymbol{I}_{k, t}=d_{k, t} \\
& I_{k, 0}=I_{k}^{i n i t} \\
& \sum_{k=1}^{K} \sum_{z=1}^{Z} f_{j, k, z} \bullet x_{k, t+z}=b_{j, t} \\
& \sum_{m a=1}^{M A} \sum_{s=1}^{S} \operatorname{Mit}_{m a, j, s, t} \bullet K A P A_{m a, t}=a_{j, t} \\
& a_{j, t} \leq a_{j, t}^{\max } \\
& \sum_{s=1}^{S} \operatorname{Mit}_{m a, j, s, t-1}+m_{m a, j, t-Y}-n_{m a, j, t-W}=\sum_{s=1}^{S} \operatorname{Mit}_{m a, j, s, t} \\
& \operatorname{Mit}_{m a, j, s, 0-Z}=M i t_{m a, j, s}^{i n i t} \\
& \sum_{s=1}^{S} \operatorname{Mit}_{m a, j, s, t} \geq \operatorname{Mit}_{m a, j, t}^{\min } \\
& \sum_{s=1}^{S} \operatorname{Mit}_{m a, j, s, t} \leq \mathrm{Mit}_{m a, j, t}^{\max } \\
& b_{j, t} \leq R_{j}^{\max } \bullet a_{j, t} \\
& b_{j, t} \leq \boldsymbol{R}_{j}^{\mathrm{min}} \bullet a_{j, t} \\
& \sum_{m a=1}^{M A} \operatorname{Mit}_{m a, j, s, t} \geq p_{j, s, t} \bullet S_{j, s}^{U n t} \\
& \sum_{m a=1}^{M A} M_{i t} t_{m a, j, s, t} \leq p_{j, s, t} \bullet S_{j, s}^{\text {oben }} \\
& \sum_{s=1}^{S} p_{j, s, t}=1
\end{aligned}
$$


Examination Scenarios and Case Study

The scenarios differ between their assumed human fatigue courses and their product requirement classes. There are three different human fatigue courses $(1=$ flat exponential course, $2=$ steep exponential course, $3=$ constant course). Thereby course 3 is equal to the non-consideration of worker utilization specific processing times or rather it means that no human fatigue occurs. Courses 1 and 2 are chosen, because an exponential course is often used in literature (see: [15] [16]). The weighting factors for the worker utilization specific processing times due to the different courses are presented in Figure 1. These factors are taken into account to calculate the appropriate processing times for each worker utilization, product and production segment.

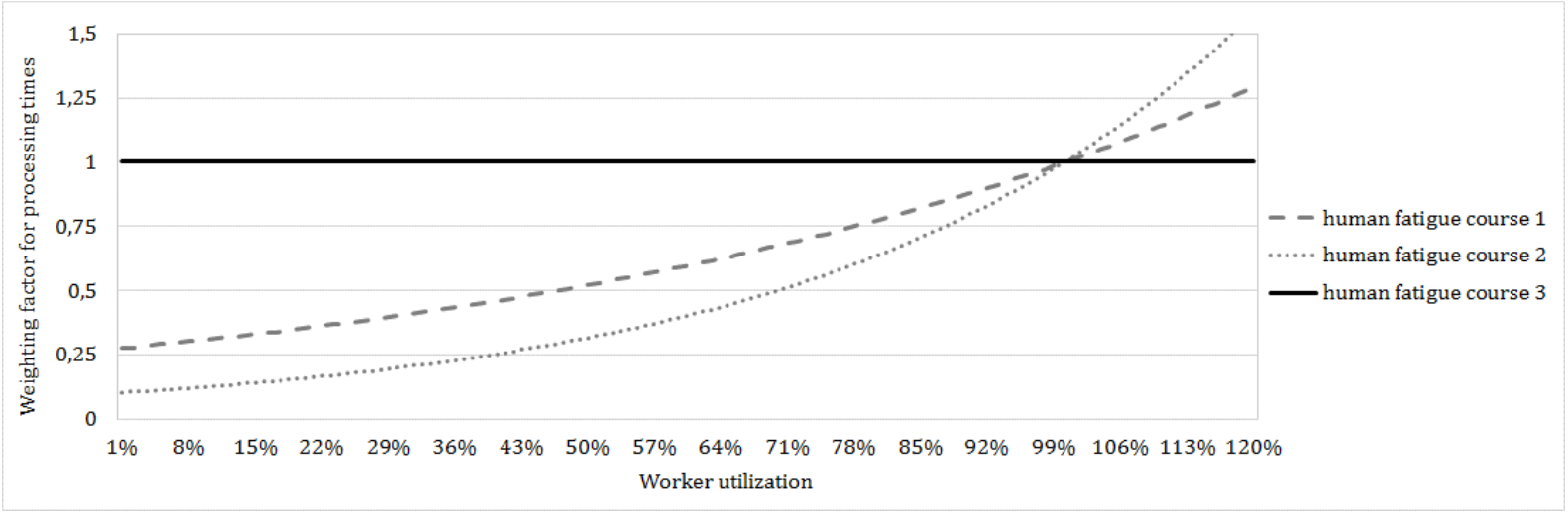

Source: Own

Fig. 1: Worker utilization specific weighting factors for processing times per human fatigue courses

Next to this there are also three product requirement classes $(1=$ medium requirements, $2=$ small requirements, 3 = large requirements), which are determined based on the results for capacity requirements of the higher planning level - the Aggregated Production Planning. Furthermore, there are three different and randomly defined product requirement sequences per product requirement class, so that there are 9 different requirement sequences in total. In conjunction with the human fatigue courses this result in overall 27 different examination scenarios.

In addition, the considered worker utilization should not decrease arbitrary and to establish a concrete point of worker utilization is not practicable. Another aspect, which should be considered, is that worker utilization from more than $100 \%$ also should not be recommended due to social aspects. That is why we use these four different worker utilization intervals 80$85 \%, 85-90 \%, 90-95 \%$ and $95-100 \%$. Associated with the two regarded production segments 16 different worker utilization constellations have to been calculated per examination scenario to determine the optimal solutions for each of the 27 scenarios. Further used parameters are presented in [5]. Differences occur by the standard processing times, which are in this paper at the first production segment 2534 time units per quantity units (TU/QU) for product A and $4735 \mathrm{TU} / \mathrm{QU}$ for product $\mathrm{B}$ as well as $7019 \mathrm{TU} / \mathrm{QU}$ for product $\mathrm{A}$ and $6632 \mathrm{TU} / \mathrm{QU}$ for product $\mathrm{B}$ at the second production segment and there is also considered that only a part of the processing times (manual part) is affected by the worker utilizations. These proportions are $80 \%$ in production segment 1 and 30\% in production segment 2 .

Finally, for the additional calculation of costs for shift bonuses, the manpower costs are multiplied with the factors $0.0 \%$ for one shift models, $1.5 \%$ for two shift models and $15.0 \%$ for three shift models. 
First the deviations between the optimal solutions with and without consideration of worker utilizations are presented in Figure 2. Classically it is expected that a maximization of the utilization leads to the optimal solution. Therefore, we compare the determined real optimal solution from our optimization model with the solution for the maximal worker utilization, which is identical with a non-consideration of worker utilizations. For this case, the worker utilization constellation from $95-100 \%$ for each production segment is taken into account to calculate the solutions for non-consideration of worker utilizations.

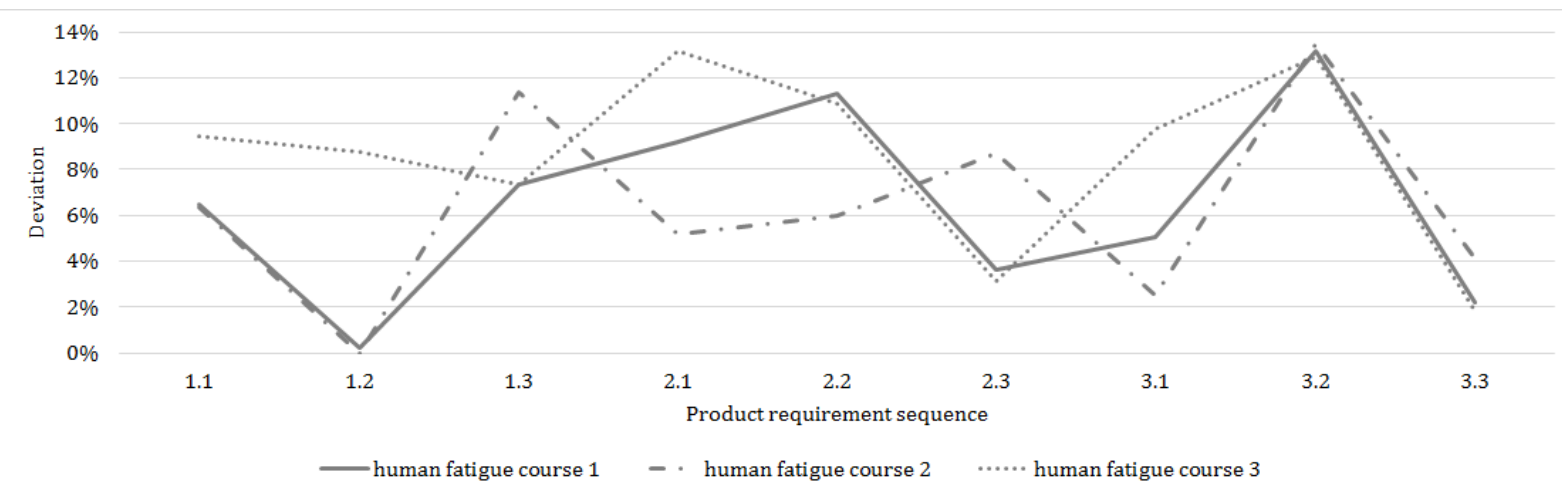

Source: Own

Fig. 2: Deviations between solutions with and without consideration of worker utilizations

From Figure 2 it emerges that the solutions without consideration of worker utilizations deviate from the optimal solutions by $7.2 \%$ in average about all requirement sequences and human fatigue courses. The deviations in average per product requirement class (average per requirement sequences at the same requirement class) demonstrate that this result is not caused by specific demand sequences, because the deviation to each product requirement class is always between $6 \%$ and $8 \%$. Therefore it is shown that the ignorance of worker utilizations causes essential deviations from reality, so that more defected production plans, cost budgets and personnel plans occur and disadvantages in competition and overloading from workers are the consequences. Next to this, the real optimal solutions are presented at table 1, together with the deviations between a consideration and non-consideration of worker utilization specific processing times. In this context, the fatigue course 3 was used to represent the case of a non-consideration of worker utilization specific times.

Tab. 1: Optimal solutions [in money units] and deviations between consideration and nonconsideration of worker utilization specific processing times

\begin{tabular}{|c|c|c|c|c|c|c|c|}
\hline \multirow{2}{*}{$\begin{array}{l}\text { Requirement } \\
\text { Sequence }\end{array}$} & \multicolumn{3}{|c|}{$\begin{array}{c}\text { Optimal Solution dependent on } \\
\text { Human Fatigue Course } \\
\end{array}$} & \multirow{2}{*}{\multicolumn{2}{|c|}{$\begin{array}{c}\text { Deviation } \\
\text { between } 3 \& 1\end{array}$}} & \multirow{2}{*}{\multicolumn{2}{|c|}{$\begin{array}{c}\text { Deviation } \\
\text { between } 3 \& 2\end{array}$}} \\
\hline & 1 & 2 & 3 & & & & \\
\hline 1.1 & 132797 & 132949 & 129215 & $2.70 \%$ & \multirow{3}{*}{$3.51 \%$} & $2.81 \%$ & \multirow{3}{*}{$4.86 \%$} \\
\hline 1.2 & 144159 & 144504 & 132885 & $7.82 \%$ & & $8.04 \%$ & \\
\hline 1.3 & 123092 & 118660 & 123082 & $0.01 \%$ & & $3.73 \%$ & \\
\hline 2.1 & 128789 & 133677 & 124303 & $3.48 \%$ & \multirow{3}{*}{$1.46 \%$} & $7.01 \%$ & \multirow{3}{*}{$5.63 \%$} \\
\hline 2.2 & 133248 & 139995 & 133748 & $0.38 \%$ & & $4.46 \%$ & \\
\hline 2.3 & 130483 & 124424 & 131145 & $0.51 \%$ & & $5.40 \%$ & \\
\hline 3.1 & 133511 & 136770 & 127739 & $4.32 \%$ & \multirow{3}{*}{$1.62 \%$} & $6.60 \%$ & \multirow{3}{*}{$3.10 \%$} \\
\hline 3.2 & 133780 & 133398 & 134035 & $0.19 \%$ & & $0.48 \%$ & \\
\hline 3.3 & 127142 & 124783 & 127566 & $0.33 \%$ & & $2.23 \%$ & \\
\hline
\end{tabular}

Source: Own 
From table 1 it emerges that the optimal solutions from the human fatigue course 3 deviate by $3.4 \%$ in average about all requirement sequences and other human fatigue courses. But the deviation in average about all requirement sequences between human fatigue course 3 and 1 $(2.19 \%)$ is only half as high as the comparable deviation between human fatigue course 3 and $2(4.53 \%)$. So, for one thing it is shown that the consideration of worker utilization specific processing times has an important impact, but on the other hand it is also important to take into account the right human fatigue course, what is a gap in research actual. Therefore, to prevent more defected production plans, cost budgets and personnel plans the consideration of worker utilization specific processing times is also a necessity. However, further research activities are necessary to quantify fatigue effects correctly, like it is done for human learning effects.

\section{Conclusion}

At this paper, it is demonstrated that there is a gap in research for the integration of the social dimension along the Production Planning and Control. Especially approaches with considered social criteria are missing at the level of Master Production Scheduling. Therefore, an appropriate optimization model is presented and 27 different scenarios are analyzed. From the results, it emerges that advantages in competition and a reduction of worker's stress could be achieved by considering optimal worker utilizations and worker utilization specific processing times. That means that a timely consideration of social effects causes a more carefully use of the human resources but also monetary advantages. Finally, a gap in research is recognized for quantifying right fatigue courses, which should be solved in further research activities.

\section{Acknowledgements}

Mr. Marco Trost is funded by the European social fund Saxony (application number 100235479) for projects for the promotion of national innovation promotions (funding period 01.10.2015 - 31.12.2018).

\section{Literature}

[1] ROGALL, H. (2009). Nachhaltige Ökonomie - Ökonomische Theorie und Praxis einer Nachhaltigen Entwicklung. Metropolis, Marburg.

[2] HAASIS, H.-D. (2008). Produktions- und Logistikmanagement - Planung und Gestaltung von Wertschöpfungsprozessen. Gabler, Wiesbaden.

[3] VORDERWINKLER, M. and HEISS, H. (2011). Nachhaltige Produktionsregeln. Berichte aus Energie- und Umweltforschung. 40/2011. Bundesministerium für Verkehr, Innovation und Technologie, Wien.

[4] TROST, M.; CLAUS, T.; HERRMANN, F.; TEICH, E.; SELMAIR, M.: (2016). Social and ecological variables in hierarchical production planning. Proceedings of European Conference on Modelling and Simulation. 30, pp. 432-438.

[5] TROST, M.; TEICH, E.; CLAUS, T.; HERRMANN, F.: (2017). Ein lineares Optimierungsmodell zur Hauptproduktionsprogrammplanung mit Berücksichtigung sozialer Größen. uwf UmweltWirtschaftsForum. 25(1-2), pp. 71-80. DOI: $\underline{10.1007 / \mathrm{s} 00550-017-0454-7}$

[6] ABSI, N.; DAUZÈRE-PÉRÈS, S.; KEDAD-SIDHOUM, S.; PENZ, B.; RAPINE, C.: (2013). Lot sizing with carbon emission constraints. European Journal of Operational Research. 227(1), pp. 55-61. DOI: 10.1016/j.ejor.2012.11.044 
[7] BATTINI, D.; PERSONA, A.; SGARBOSSA, F.: (2014). A sustainable EOQ model: theoretical formulation and applications. International Journal of Production Economics. Vol. 149, pp. 145-153. DOI: 10.1016/j.ijpe.2013.06.026

[8] BOUCHERY, Y.; GHAFFARI, A.; JEMAI, Z.; DALLERY, Y.: (2012). Including sustainability criteria into inventory models. European Journal of Operational Research. 222(2), pp. 229-240. DOI: 10.1016/j.ejor.2012.05.004

[9] JABER, M. Y.; BONNEY, M.: (2007). Economic manufacture quantity (EMQ) model with lot-size dependent learning and forgetting rates. International Journal of Production Economics. 108(1-2), pp. 359-367. DOI: 10.1016/j.ijpe.2006.12.020

[10] LAI, P.-J.; LEE, W.-Ch.: (2013). Single-machine scheduling with learning and forgetting effects. Applied Mathematical Modelling. 37(6), pp. 4509-4516. DOI: $10.1016 /$ j.apm.2012.09.066

[11] BOYSEN, N.; FLIEDNER, M.: (2011). Scheduling aircraft landings to balance workload of ground staff. Computers \& Industrial Engineering. 60(2), pp. 206-217. DOI: $10.1016 /$ j.cie.2010.11.002

[12] DREXL, A.; FLEISCHMANN, B.; GÜNTHER, H. O.; STADTLER, H.; TEMPELMEIER, H.: (1993). Konzeptionelle Grundlagen kapazitätsorientierter PPSsysteme (No. 315). Manuskripte aus den Instituten für Betriebswirtschaftslehre der Universität Kiel. [online]. Available from WWW: http://hdl.handle.net/10419/155400

[13] SCHMUCKER, R.: (2014). DGB-Index Gute Arbeit - Der Report 2013. Institut DGBIndex Gute Arbeit, Berlin. [online]. Available from WWW: http://index-gutearbeit.dgb.de/++co++20acc212-dec2-11e3-a855-52540023ef1a

[14] GÜNTHER, H.-O.; TEMPELMEIER, H.: (2012). Produktion und Logistik. 9. Auflage. Springer, Berlin, Heidelberg, New York. ISBN 978-3642251641.

[15] JABER, M. Y.; GIVI, Z. S.; NEUMANN, W. P.: (2013). Incorporating human fatigue and recovery into the learning-forgetting process. Applied Mathematical Modelling. 37(12-13), pp. 7287-7299. DOI: 10.1016/j.apm.2013.02.028

[16] ZHANG, Z.; LI, K. W.; ZHANG, W.; MA, L.; CHEN, Z.: (2014). Muscular fatigue and maximum endurance time assessment for male and female industrial workers. International Journal of Industrial Ergonomics. 44(2), pp. 292-297. DOI: $10.1016 /$ j.ergon.2012.08.006 


\section{NUTNOST INTEGRACE SOCIÁLNÍCH KRITÉRIÍ DO PLÁNOVÁNÍ PROGRAMU HLAVNÍ PRODUKCE}

Př́spěvek zkoumá nutnost zohlednění vytížení spolupracovníků a na něm závislé pracovní doby v hlavním plánování programu hlavní produkce. Navíc je ukázáno, že tato tematická oblast aktuálně představuje ve výzkumu mezeru. Z tohoto důvodu je tu představen vlastnoručně vyvinutý lineární model optimalizace na plánování programu hlavní produkce, který obsahuje sociální kritéria a vhodnou př́padovou studii. Výsledky ukazují, že značné odchylky jsou odvislé od ignorance při vytížení spolupracovníků v pracovní době. Z tohoto důvodu je doporučována integrace. Zároveň se ukazuje, že bude třeba dalšího výzkumu, obzvlášst pro stanovení vhodných vytěžujících funkcí, jako jsou napřr. funkce pro efekty $\mathrm{v}$ učení.

\section{VON SOZIALEN KRITERIEN IN DIE HAUPTPRODUKTIONSPROGRAMMPLANUNG}

Folgender Beitrag untersucht die Notwendigkeit einer Berücksichtigung von Mitarbeiterauslastungen und davon abhängiger Bearbeitungszeiten in der Hauptproduktionsprogrammplanung. Zudem wird aufgezeigt, dass dieses Themengebiet aktuell eine Forschungslücke darstellt. Aus diesem Grund wird ein selbst entwickeltes lineares Optimierungsmodell für die Hauptproduktionsprogrammplanung vorgestellt, welches soziale Kriterien und eine geeignete Fallstudie enthält. Die Ergebnisse verdeutlichen, dass erhebliche Abweichungen durch eine Ignoranz von Mitarbeiterauslastungen und davon abhängiger Bearbeitungszeiten entstehen. Deshalb ist eine Integration $\mathrm{zu}$ empfehlen. Allerdings wird auch deutlich, dass weitere Forschungen notwendig sind, speziell für die Bestimmung geeigneter Erschöpfungsfunktionen, so wie beispielsweise Funktionen für Lerneffekte existieren.

\section{KONIECZNOŚĆ INTEGRACJI KRYTERIÓW SPOŁECZYCH W PLANOWANIU PROGRAMU GŁÓWNEJ PRODUKCJI}

W niniejszym artykule zbadano konieczność uwzględnienia obciążenia współpracowników i od niego zależnego czasu pracy w głównym planowaniu programu głównej produkcji. Ponadto wskazano, że ta dziedzina jest obecnie w badaniach pomijana. $Z$ tego względu przedstawiono opracowany we własnym zakresie model liniowy optymalizacji planowania programu głównej produkcji, obejmujący kryteria społeczne oraz odpowiednie studium przypadku. Wyniki pokazują, że znaczne odchylenia wynikają z ignorancji przy obciążaniu współpracowników w czasie pracy. Z tego powodu zalecana jest integracja. Ponadto wskazano, że konieczne są kolejne badania, w szczególności w celu określenia odpowiednich funkcji obciążeniowych takich jak np. funkcja dla efektów w uczeniu się. 